\title{
THE IMPLEMENTATION OF INTERACTIVE MULTIMEDIA WITH MACROMEDIA FLASH 8.0 IN BIOLOGICAL LEARNING AT SMK IBRAHIMY 2 SUKOREJO
}

\author{
Dyan Yuliana ${ }^{1}$, Achmad Fauzan Azzubair ${ }^{2}$ \\ ${ }^{12}$ Information Technology Education Study Program, STKIP PGRI Situbondo, Indonesia \\ Jl. Argopuro Gg. VII Mimbaan Village, Panji District, Situbondo Regency \\ *Corresponding Author: pitikpitik23@gmail.com
}

\begin{abstract}
The application of technology in the form of computer applications as learning media, such as Macromedia Flash 8.0, can be implemented in learning in order to achieve the expected quality of education and learning outcomes. Biology subjects require materials / materials / objects that are sometimes difficult to present in a real class or in front of students, but by using the Macromedia Flash 8.0 application media these objects can be presented and told in an attractive animation form so as to increase student interest and motivation. This study aims to apply learning media with Macromedia Flash 8.0 in biology class $X$ subject and determine the feasibility of the software being developed. This research is a development research conducted in four stages, including: analysis; design; production; and evaluation. Data obtained from a questionnaire and given a score on a scale of 1-5. The results showed that the learning media with Macromedia Flash 8.0 resulted in the quality of learning media based on the results of the material expert's test with a score of 3.85 in a good category, the results of the media expert test had a score of 4.2 in a good category, and the results of testing on users (students) with a score of 4.4 in the very good category. So, it was concluded that the learning media product with the Macromedia Flash 8.0 Program was effective and suitable for use in the Biology learning process for class X ATP students at SMK Ibrahimy 2 Sukorejo
\end{abstract}

Keywords: Interactive Multimedia, Macromedia Flash 8.0, Biology Learning

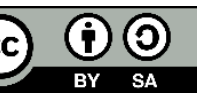

\section{PRELIMINARY}

The education system is growing very fast. In recent years, information and communication technology has been widely used in the learning process to improve the quality of education in line with technological advances. The development of multimedia technology provides great potential in changing the way a person learns, acquires and adjusts information, and so on. Multimedia also provides opportunities for educators to develop learning techniques, resulting in maximum learning quality.[1] Likewise for students, learning with multimedia is expected to make it easier to absorb information more quickly and efficiently. Sources of information are no longer focused only on the text of the book, but are broader than that. The ability of multimedia technology that uses internet access will further increase the ease in obtaining the expected information.

Implementation of the application of instructional media in educational units will be very useful if synergistically supported by the availability of adequate resources and infrastructure, which in turn will have implications for improving the quality and quality of the education unit.

SMK Ibrahimy 2 Sukorejo as one of the vocational education institutions under the auspices of the Salafiyah Syafi Islamic Boarding School Foundation "iyah Sukorejo, Sumberejo Village, Banyuputih District, Situbondo Regency, East Java, in management and the curriculum implemented is by integrating the National Vocational School curriculum with the Salafiyah Syafi 'Pondok Pesantren curriculum. Yes, Sukorejo. The integration of the national vocational high school curriculum with the pesantren curriculum is reflected in the characterization of the pesantren's character, including the separation of the male and female classes, the cultivation of social cultural characters / ahlaqul karimah, ways of clothing, learning morals, Arabic grammar and reading the Qur'an.

The inculcation of pesantren characters as the hallmark of SMK Ibrahimy 2 Sukorejo in synergy 
continues to be developed according to the needs and demands of the community, especially vocational education. In the educational process, both theory / practice, quality improvement is carried out by involving all potentials, including foundations, dudi, almumni and the community.

In the process of teaching and learning activities (KBM) at SMK Ibrahimy 2 Sukorejo continuously the foundations, schools and supervisors periodically (every semester) carry out an evaluation process, especially in the preparation of learning tools and methodologies that are applied by the teachers / instructors in the class. This evaluation is urgent considering the success and absorption of students on subject matter, one of which is due to the methodology, tools and media applied by the teacher.

Implementing computer applications such as GSP, Adobe Flash CS 4, Macromedia Flash 8.0, and others as interactive and efficient learning media is something that must be done in order to improve the quality of the process and the results of learning. Including at SMK Ibrahimy 2 Sukorejo, the application of technology media in learning is absolutely necessary to achieve the expected quality of educational and learning outcomes, especially in the subject of learning materials / materials / objects that are difficult to present in the classroom, such as in Biology, where subjects Biology requires that not only be conveyed through stories but through evidence that can be presented in a congress can be seen in front of students, then using the Macromedia Flash 8.0 application media is expected to increase the achievement of competencies expected in each basic Competency Indicator and Subject.

Based on the description above, it can be concluded that the importance of implementing learning media using attractive animation. The role of media in the form of animation can help the learning process become more effective and efficient, so researchers are interested in conducting research entitled Implementation of Interactive Multimedia with Macromedia Flash 8.0 in Biology Learning at SMK Ibrahimy 2 Sukorejo.

Research conducted by Saiful Arifin in 2008 with the title "Procedures and Effectiveness of Learning Media Development Book of Matnul Ghoyah Wat Taqrib Chapter Haj Using Macromedia Flash 8.0 at Pesantren Luhur Al-Husna Surabaya". This research focuses on procedures and effectiveness in the development of learning media for the book of Matnul Ghoyah Wat Taqrib chapter Hajj using Macromedia Flash 8.0 at Pesantren Luhur Al-Husna Surabaya. The results of this study indicate that the development of learning media using
Macromedia Flash 8 in Islamic Boarding School Luhur al-Husna Surabaya uses a modified Alessi and Trollip model. The media is considered effective enough to support the learning of the Taqrib book of the haj chapter. [2]

The next research was conducted by Akhmad Badri in 2012 entitled "Development of WebsiteBased Macromedia Flash Learning Media on Linear Program Material in Class XII SMA". This study presents a website-based Macromedia Flash which was developed as a learning medium on Linear Program material in Class XII SMA. [3]

Research conducted by Sultan Muhammad Zahirul Alam in 2012 with the title "Utilization of Learning Media Using Macromedia Flash 8.0 in teaching Jenazah Prayers at SMP Islam Sidoarjo". This study describes the use of Macromedia Flash 8.0 as a medium in teaching Jenazah Prayers in class VII SMP Islam Sidoarjo. Through the Macromedia Flash 8.0 learning media, students' interest in learning is increasing in learning the Jenazah Prayer material. [4]

Media are all forms of intermediaries used by humans to convey or spread ideas, ideas or opinions so that the ideas, ideas or opinions expressed reach the intended recipient. [5]

Media is divided into five groups, namely: human-based media, print-based media, visualbased media, audio-visual-based media, and computer-based media. Media can also be grouped into print media, display media, overhead transparency, sound recordings, slides and filmstrips, multi-image presentations, videos and films, computers. [5]

Based on the definitions above, it can be concluded that the types of media are as follows: audio media, visual media, audio visual media, and electronic media.

Effective learning requires good and thorough preparation. The media to be used in learning activities also require good preparation and planning. However, the reality in the field shows that educators choose one of the media in their class activities on the basis of consideration because they feel familiar with the media, they feel that the media they choose can describe better than themselves, the media they choose can attract students' interest and motivation to learn. and can assist in the presentation of teaching materials in a more structured and organized manner.

In selecting learning media, you should consider the following matters :

a. The ability to accommodate the presentation of the stimulus appropriately. 
b. Ability to accommodate students' responses appropriately.

c. Ability to accommodate feedback.

d. Selection of primary media and secondary media in presenting information or stimuli and for practice and tests should use the same media. [5]

Interactive multimedia is multimedia that is equipped with a controller that can be operated by the user, so that the user can choose what he wants for the next process. Examples of interactive multimedia are interactive learning, game applications. Interactive multimedia is multimedia that is equipped with a controller that can be operated by the user so that the user can choose what he wants for the next process. [6]

Interactive multimedia is a combination of several types and forms of media used in a systematic and structured presentation of the material. Interactive multimedia aims to present information in a form that is attractive, easy to understand, and not boring. The use of the five senses is very helpful in absorbing information so that it is easier to understand.

Macromedia Flash 8 is a software version of Macromedia.inc in the form of graphics and animation programs whose existence is intended for design and animation lovers to create interactive web animation, cartoon animation, company profile presentation of business or activity, and interesting flash games. [7]

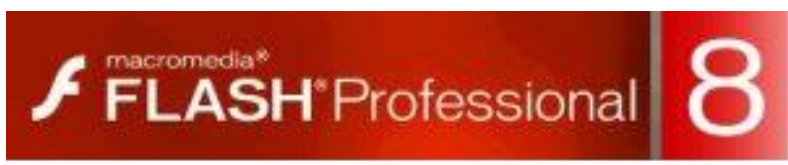

Figure 1. Macromedia flash professional 8.0 logo

Through the use of the Macromedia Flash application, we can create several types of applications as follows :

a. Application Animations

The use of this animation, for example, in online greeting cards, cartoons, and advertisements.

b. Games

Many types of games, especially those based on two dimensions, are designed with this application. The game combines the animation capabilities of flash with its scripting language known as Action Script.

c. User Interface

d. User interface applications built with Macromedia Flash are web-based applications. This interface is usually equipped with simple navigation boxes to other, more complex interfaces. [8]
When you want to start creating objects (animation), you need to be familiar with several interfaces in macromedia flash 8.0. These interfaces will help you a lot in managing or editing the animated objects used. The following work area / front view (home) Macromedia Flash 8.0 :

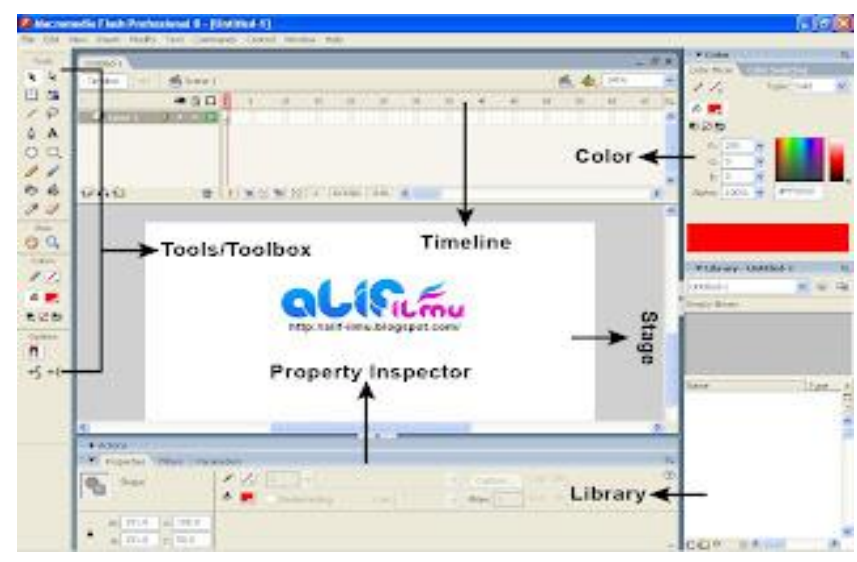

Figure 2. Macromedia flash 8.0 workspace

\section{METHOD}

This study uses a research and development approach known as Research and Development (R\&D). RnD is a research method used to produce products and test the effectiveness of certain products. Educational Research and Development is also called Research Based Development. "Educational Research and Development is a process used to develop and validate educational products". [9] Research and development is a process used to develop or validate products that are applied in learning. In general, this study aims to determine the feasibility of developing instructional media with the Macromedia Flash 8.0 program on the Biology subject, as the subject matter of Plants which will be used as a learning medium at SMK Ibrahimy 2 Sukorejo.

This research was conducted at SMK Ibrahimy 2 Sukorejo, located in Sukorejo Village, Banyuputih District, Situbondo Regency. The research was conducted in June-July 2018. The research subjects consisted of 1 media expert, 1 material expert, and 22 students of class X ATP on field trials.

Learning media development using Macromedia Flash 8.0 has the following stages :

1) Stages of Analysis

The analysis stage is the preliminary stage before determining the concept of making Macromedia Flash learning media. Activities carried out include :

a. Identify the purpose of learning media.

b. Identify the characteristics of students. 


\section{2) Design Stages}

The design stage is carried out before determining the initial product design concept of learning media with Macromedia Flash 8.0. The initial activities carried out were :

a. Design learning materials.

b. Designing instructional media designs using Macromedia Flash 8.0 program.

3) Production Stages

The production stage is the stage of organizing various lay-outs, designs, and various types of materials that have been prepared into an interactive multimedia product. The steps taken include :

a. Producing learning material about plants.

b. Authoring of Plant learning materials.

c. Editing of Plant learning materials.

4) Evaluation Stages

Learning media is evaluated(assessed) by several expert teams to determine the validation of learning media, materials, and learning quality. The stages taken are:

a. Material expert due diligence.

b. Test the feasibility of media experts.

c. Product trials on users (students).

Data collection techniques used include: observation, interviews, questionnaires, and documentation. Initial observations were made to obtain data as the basis for conducting development research. Interviews were conducted with Biology subject teachers and students to obtain data related to the needs in this study, such as identifying student needs in learning, especially Biology subjects with the subject of the level of living organisms in plants. The questionnaire is used to determine the responses of material experts, media experts, and students regarding the development of learning media using Macromedia Flash 8.0 and to determine the feasibility of the product as a basis for revising the product. The documentation technique is in the form of a data collection process by searching for the manuals needed to create a Biology learning media on the Level of Life Organisms in plants for class X ATP students at SMK Ibrahimy 2 Sukorejo.

The data analysis technique used in this research is descriptive analysis. The data obtained from the questionnaire is then converted into a value on the following scale of $5:[10]$

Table 1.Conversion of Score to Value on a Scale of 5

\begin{tabular}{lcc}
\multicolumn{1}{c}{ Score Interval } & Score & Category \\
\hline $\mathrm{X}>\mathrm{Mi}+1,8 \mathrm{SBi}$ & $\mathrm{A}$ & Very good \\
$\mathrm{Mi}+0,6 \mathrm{SBi}<\mathrm{X} \leq \mathrm{Mi}+1,8$ & $\mathrm{~B}$ & Good \\
$\mathrm{SBi}$ & & \\
$\mathrm{Mi}-0,6 \mathrm{SBi}<\mathrm{X} \leq \mathrm{Mi}+0,6$ & $\mathrm{C}$ & Enough good \\
$\mathrm{SBi}$ & & \\
\hline
\end{tabular}

\begin{tabular}{lcc}
\hline $\mathrm{Mi}-1,8 \mathrm{SBi}<\mathrm{X} \leq \mathrm{Mi}-0,6$ & $\mathrm{D}$ & Less good \\
$\mathrm{SBi}$ & $\mathrm{E}$ & Very less good \\
$\mathrm{X} \leq \mathrm{Mi}-1,8 \mathrm{SBi}$ &
\end{tabular}

Information :

- X = actual score (empirical)

$-\mathrm{Mi}=$ ideal mean, calculated using the formula :

$\mathrm{Mi}=1 / 2$ (ideal maximum score + ideal minimum

score) (1)

- $\mathrm{SBi}=$ ideal standard deviation, determined by the

formula :

$\mathrm{SBi}=1 / 6$ (ideal maximum score - ideal minimum

score) (2)

From the scale of 5 , it is obtained that the ideal maximum score $=5$ and the ideal minimum score $=$ 1 , so that the results of the calculation of Mi and Sbi are :

$$
\begin{aligned}
& -\mathrm{Mi}=1 / 2(5+1)=3 \\
& -\mathrm{SBi}=1 / 6(5-1)=0,67
\end{aligned}
$$

Based on the above provisions, the results of the scale 5 calculation are as follows :

Table 2. Conversion of Quantitative Data into Qualitative Data with a Scale of 5 and EAP Approach

\begin{tabular}{|c|c|l|l|}
\hline \multirow{2}{*}{ Scale } & \multirow{2}{*}{ Criteria } & \multicolumn{2}{|c|}{ Score } \\
\cline { 3 - 4 } & & \multicolumn{1}{|c|}{ Calculation } & \multicolumn{1}{c|}{ Result } \\
\hline 5 & Very good & $\mathrm{X}>3+(1,8 \times 0,67)$ & $\mathrm{X}>4,2$ \\
\hline 4 & Good & $\begin{array}{l}3+(0,6 \times 0,67)<\mathrm{X} \leq \\
3+(1,8 \times 0,67)\end{array}$ & $\begin{array}{l}3,4<\mathrm{X} \leq \\
4,2\end{array}$ \\
\hline \multirow{2}{*}{3} & $\begin{array}{c}\text { Enough } \\
\text { good }\end{array}$ & $\begin{array}{l}3-(0,6 \mathrm{x} 0,67)<\mathrm{X} \leq \\
3+(0,6 \mathrm{x} 0,67)\end{array}$ & $\begin{array}{l}2,6<\mathrm{X} \leq \\
3,4\end{array}$ \\
\hline \multirow{2}{*}{2} & Less good & $\begin{array}{l}3-(1,8 \times 0,67)<\mathrm{X} \leq \\
3-(0,6 \times 0,67)\end{array}$ & $\begin{array}{l}1,8<\mathrm{X} \leq \\
2,6\end{array}$ \\
\hline \multirow{2}{*}{1} & $\begin{array}{c}\text { Very less } \\
\text { good }\end{array}$ & $\mathrm{X} \leq 3-(1,8 \times 0,67)$ & $\mathrm{X} \leq 1,8$ \\
\hline
\end{tabular}

\section{RESULTS AND DISCUSSION}

The product produced in this study is an interactive learning media for Biology subject, the competency standard describes foreign exchange in the plant world and its role for survival on earth for class X ATP students at SMK Ibrahimy 2 Sukorejo. The interactive media in this study were audio-visual media using Macromedia Flash 8.0 software and packaged in the form of a $C D$ containing learning material on the Levels of Living Organisms in Plants and tested for their feasibility through tests of material experts, media experts, and users (students).

Based on the results of the tests that have been carried out, the following are the shortcomings of the program that has been made, that is :

1. In this learning program the sound dabbing and musical instruments accompanying the display of the application are not yet presented in the overall appearance of the application program. 
2. On the main menu of the exercise button, the exercise view is still not usable because the interactive game of this learning program is still not finished.

The results of the validation of the material aspects can be seen the quality of the material contained in the learning media developed. Validation by material experts aims to determine the suitability of the material needed by students. The material aspect relates to the suitability of the material with the standards of basic competence / competence, the suitability of indicators with the standards of basic competence / competence, consistency between basic competencies, indicators, material, and evaluation, accuracy of material coverage, correctness of material, update (up to date) of material, reliability. material, delivery of coherent material, useful material, depth of material, material interest (weighted), attractiveness of material, ease of delivery of material, provision of evaluation to measure student ability, providing continuous evaluation of each sub-material, involvement and role of students in learning activities, accurate and reliable learning resources, use of language, quality of material presentation, and quality of feedback to increase student motivation.

With the results of the validation of the media aspects, it can be seen that the quality of the display and the learning media program being developed. These media aspects include: font type selection, font size selection, color, graphics, accuracy of background selection, image display, animation, accompaniment music, sound, screen design , use of language, navigation, button consistency „, clarity of instructions for use, ease of use , the efficiency of using layers, the efficiency of the text, the speed, and the anticipation of the possible responses of students.

The results of trials on users (students) serve as the basis for determining the suitability of the material to the needs of students. These aspects relate to the clarity of instructions for using the program, readability of text / writing, quality of image display, animation presentation, color composition, accuracy of background selection, musical support capacity, navigation, clarity of SK and $\mathrm{KD}$ that must be mastered, clarity of study instructions, ease of understanding sentences in text / writing, the ease of understanding the material / content of the lesson, the accuracy of the presentation order, the scope of the quiz training / delivery, the role of learning media to add insight and knowledge, and clarity of feedback / response, in increasing student learning interest.
Based on the overall product test results by material experts, media experts, and users (students) to assess the feasibility of media in the form of interactive learning media in Biology subjects, the following results are obtained :

1) The results of the material expert test showed an average result of 3.85 or $77 \% \rightarrow$ Good.

2) The results of the media expert test obtained an average of 4.2 or $80 \% \rightarrow$ Good.

3 ) he results of the feasibility test according to users (students) are 4.4 or $85 \% \rightarrow$ Very Good.

The results of the feasibility study of interactive learning media on Biology subjects at SMK Ibrahimy 2 Sukorejo can be seen in the diagram below :

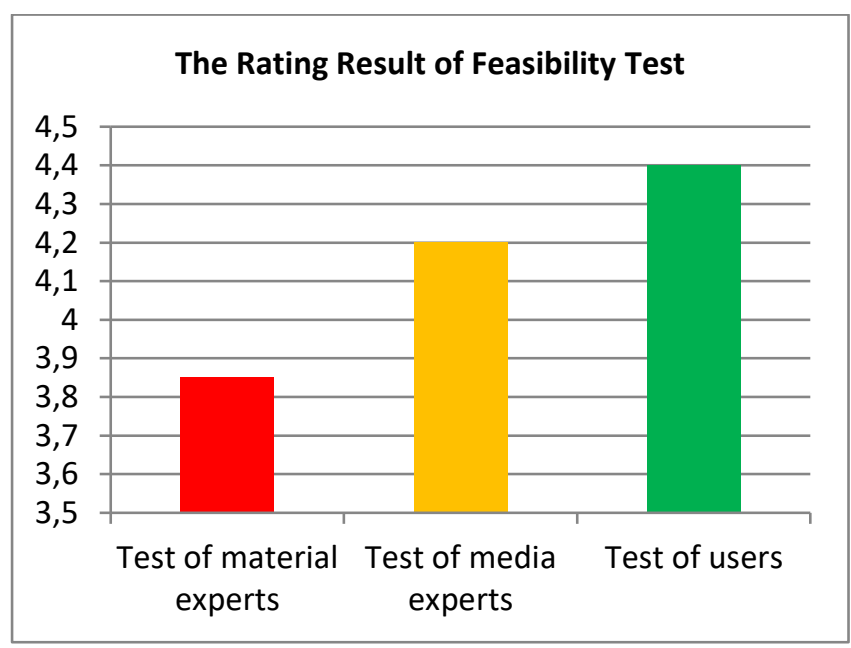

Figure 2. Diagram of the rating results of feasibility test by material experts, media experts, and users

The development of learning media using Macromedia Flash 8.0 is packaged in the form of a Compact Disk (CD). The product development uses Macromedia Flash 8.0 software which has been published in the form of extensions (.swf), (. Exe) and HTML. This learning media has been validated by 1 material expert and 1 media expert and is in accordance with the stages of research and development. The results of trials on users (students) obtained an average score of 4.4 with very good criteria.

The results of developing this learning media product have advantages and disadvantages. The advantages of the products produced in this study include:

a. The performance is different from the previous learning media, this learning media is an interactive learning media that can be used by teachers and students anytime and anywhere.

b. Presentation of material that is displayed with several animations, quizzes, and summaries is a 
unique and interesting attraction on learning media with the Macromedia Flash 8.0 program,

c. Has several interactive and consistent navigation buttons to make it easier for students to open each slide easily,

d. The characteristics of the program with a very small file size allow this program to be very easily uploaded to the internet.

e. This program has an autorn file and is immediately executed / running because it has been published to the .Exe format, so, this program doesn't need to be installed first on the device / PC to be used.

f. Can be used for independent learning.

While the shortcomings of learning media

with Macromedia Flash 8.0 are :

1) Limited subject matter conveyed in this learning media, which only covers the subject of Cells, Tissues, Organs, Organ Systems, and Plant Organisms. The subject matter does not yet cover the entire material in Biology class X ATP due to the limited time and knowledge of researchers in developing the Macromedia Flash 8.0 program.

2) Cannot be run on VCD / DVD Player, so schools that do not have computer labs for students cannot use them.

The learning media developed in this study are interactive learning media that are designed for individual learning, but educators must also continue to explain the material to help improve students' understanding, so that their learning achievement can be improved in Biology subjects and skilled in using computer technology and its application programs.

\section{CONCLUSION}

The results of data analysis and discussion can be concluded from several things including:

1. The development of learning media using Macromedia Flash 8 through several stages, including: (1) the analysis stage, namely identifying the objectives of the learning media and student characteristics; (2) the design stage, namely developing the story board, determining the layout, designing block diagrams and collecting materials in the form of graphics, images, sounds, pictures, animation, determining the application program to be used and so on; (3) the production phase, namely the organization of lay-out, design, and materials that have been prepared to become a learning media product; (4) evaluation stage, namely assessment by material experts, media experts, and trials by users (students). The results of the development of the
Macromedia Flash 8.0 program are packaged in Compact Disk (CD) form.

2. The quality of learning media products with the Macromedia Flash 8.0 Program is reviewed based on the assessment of material experts and media experts which are classified as good with an average score of 3.85 and 4.2 , while the results of the assessment by students (users) reach an average score of 4,4 with the very good category, so that the learning media with the Macromedia Flash 8.0 Program is effective and suitable for use in the Biology learning process for class X ATP students at SMK Ibrahimy 2 Sukorejo.

\section{SUGGESTION}

Based on the conclusions and limitations in this study, the researchers provide suggestions including:

1. For further research, other subjects that have not been used in this learning media should be added.

2. This learning media product is in accordance with the principles of learning design and is in accordance with the learning syllabus of Biology subjects, and has gone through the validation process both by media experts and material experts, as well as students, so educators are expected to be able to use this product in learning activities but still adjusted to the principles of learning design that apply to each Education Unit.

3. The learning media produced in this study please disseminate it in general in schools because it is very useful to support the learning process, especially Biology subjects in class X SMK.

4. Before implementing this learning media, educators are advised to try all available activities first, so that they can easily apply in class.

5. This Macromedia Flash 8.0 product is based on multimedia computers, so it is recommended that schools that already have computer laboratories equip their computers with facilities such as speakers, USB ports, CD ROMs, and the like.

6. Educators are expected to be able to utilize learning media with Macromedia Flash 8.0 in delivering subject matter to students. With the use of this learning media, it is hoped that more lessons will emerge with different subjects.

\section{REFERENCE}

[1] A. D. Samala, B. R. Fajri, F. Ranuharja, and R. Darni, "PEMBELAJARAN BLENDED LEARNING BAGI GENERASI Z DI PERGURUAN TINGGI (STUDI KASUS: PENDIDIKAN TEKNIK INFORMATIKA UNIVERSITAS NEGERI PADANG)," J. Teknol. Inf. dan Pendidik., 2020. 
[2] Akhmad Badri, "Development of WebsiteBased Macromedia Flash Learning Media on Linear Program Material in Class XII SMA", thesis, UIN Sunan Ampel, Surabaya, 2012.

[3] Andriyanto, "The Effect of Using Meida Learning Mcaromedia Flash 8.0 on Science Learning Outcomes of Class V Students at SDN Kebumen 1", essay, Satya Wacana Christian University, Salatiga, 2012.

[4] Anggra, Understanding the Basic Techniques of Making Flash-Based Games, Gava Media, Yogyakarta, 2008.

[5] Azhar Arsyad, Learning Media, PT Raja Grafindo Persada, Jakarta, 2011.

[6] Daryanto, Learning Media, PT. Gava Media, Yogyakarta, 2011.

[7] Saiful Arifin, "Procedure and Effectiveness of Learning Media Development Book Matnul Ghoyah Wat Taqrib Chapter Hajj Using Macromedia Flash 8.0 in Pesantren Luhur AlHusna Surabaya", Essay, IAIN Sunan Ampel, Surabaya, 2008.

[8] Sukardjo, Physical Chemistry, Rineka Cipta, Jakarta, 2005.

[9] Sultan Muhammad Zahirul Alam, "Utilization of Learning Media Using Macromedia Flash 8.0 in Teaching Jenazah Prayers at SMP Islam Sidoarjo", thesis, UIN Sunan Ampel, Surabaya, 2012.

[10] W.R. Borg and M.D. Gall, Educational Research: An Introduction, Fifthy Edition, Longman, New York, 1989. 